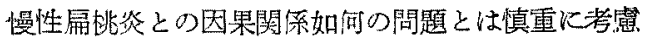

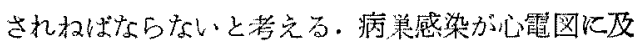
ぼす影鱀の存在を否定はしないが，その相関を過大 に評価してはならないと考克る。

\section{○1?8, 扁桃周囲膿癌の手術前后における心電図} 学的研究 吕上英明 (日發病䟚)

慢性扁兆炎の埸合の病栄感染についての報告は多

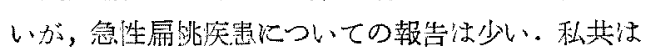

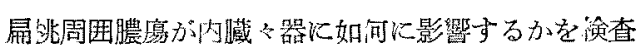
した.

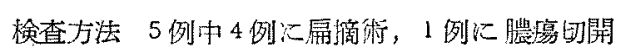

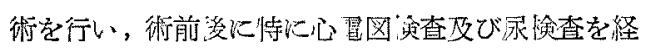
過を追つて施行した. 又細菌学的神查も併せ行つ た。

検查成績 心整図上，心筋傷害所見は5例中 4 例 飞証明した。心篦图所見は全例 ST の低下を示し， $\mathrm{PQ}, \mathrm{QRS}, \mathrm{QT}$ 時間の延唇, 低耗位差等は認わな からた，之等の心荕傷慧所見ば何れも48 時間以内 飞消失し，術㣪增悪した例はなかつた。份 4 例小， 典型的の 1 例か心電图所見を示した。

尿所見では術前 5 例中 2 例汇蛋白及びウロビリン

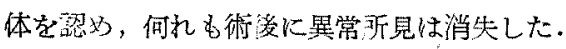

細菌学的儿は，血液培盖は全例食性，膿汁の培養 で慣色並びに白色ブドゥ球菌, 緑連菌を検出し, 摘出扁桃からは患側から溶湩菌, 黄色並びに白色ブ ドゥ冰菌, 緑連菌, グラム陰性悍菌を証明した。

これらの変化は，扁跳周囲つ炎症又、は膿澺形成な その機㳦的圧迫等が，植物神经系への侵擎となつて あらはれた生体反心の一部分として考察する見解，

即ち Reilly 氏現象の関与を提示しょ5とした。更 に之に閣する観察例について述べた。

\section{O139. 人口蓋扁挑の病理組織化学的碑究}

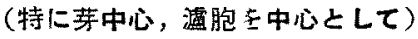
(第 1 報) 組織化学的凋究

村上作之（国立金沢）

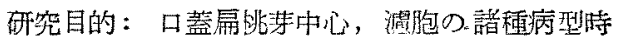

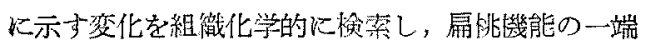
老覧わんとす

方法：85 例，115 側の 剔山新鮮標本を逐次組織
化学的裙反応の实驗に供した。

得たる知見：I）核酸証明に関する実験 a)* チール緑ピロニンでは炎症の程度に比例し, 所謂 Lymphozonia (天野)にビ・ロニン好性兽加 b) $\mathrm{Fe}$ ulgen 反応では大略的に染色され小型りンパ球及び

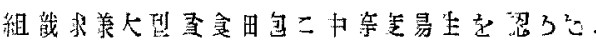

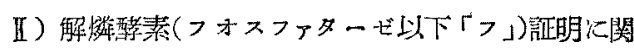
する实験，アルォッ性は㵜漫性に，酸性では細胞固 個で小型りンパ球，好中球，細血管に晹性度が高い。 III）糖翼証明に関寸る实験 過沃度酸-Schiff 反忘

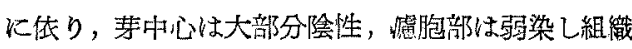
球と思われる細胞及び好中球汇中等度陽性を見た。 IV) 脂質証明汇関する契験 Sudan-Bluck に依り 芽中心，澞胞部共に基質は妈染し否哙細胞胞体に強 度陽性を見た。

\section{O140. 慢性扁桃炎に対する口蓋扁挑 マツサージの研究}

$$
\text { I 川武(島大) }
$$

慢性扁兆炎及びその病栄感染症（腎炎，関節炎，微

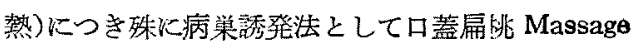
を応用し下記事項僦き花起される变化汇就いて述 べた.1. 体温：Massage 前全例の約 $2 / 3$ 飞微熱を 認め誘発法後阫桃炎群の約 60\%, 病栄感染症群て更

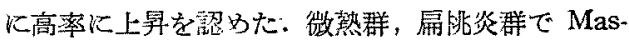
sage 後上昇傾向あるは予後良好であつた．2. 血 液像. 赤血球 $\mathrm{Hb}$ 量著变認》す⿺ 白血球数炕变化 を来たしたものもあり殊に Massage 後増加したも の怔一般渃年者に強いが病巣感染症例では高年者 む增加した．しかし遠隔成績とは必すしる一致しな からた. 3.赤沈：扁辀炎の約 $65 \%$ は中等価促進を みた。病巣感染症では Massage 後赤沈遅延したも の及び扁胜炎群では Massage 前正常籍を示したも のが 扁䐱予後良好であつた．4，尿蛋白及び尿赤血 球数は Massage で増加したものは扁捅後緊炎火対 する予後の良好のものがあつだ５．血清蛋白：病 栄感染症は $\gamma-z 1$ 高檤でむつた. 管炎では更に $\beta-\mathrm{gl}$ も多かつた。扁䐱素效群と無効群との間には Massage による蛋白商の变動に有意の差があつた． 6 .

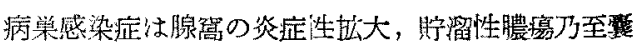
胞をもつものがー般と多かつた。 